\title{
Chitinophaga, a New Genus of Chitinolytic Myxobacteria
}

\author{
VULLAPA SANGKHOBOL AND V. B. D. SKERMAN \\ Department of Microbiology, University of Queensland, St. Lucia 4067, Brisbane, Australia
}

\begin{abstract}
Five strains of a long, filamentous, gliding microorganism which produces myxospores by transformation of filaments to spherical bodies without the production of a fruiting body were isolated from widely separated sources. These organisms are strongly chitinolytic but are not cellulolytic. We propose a new genus, Chitinophaga, containing a single species, Chitinophaga pinensis sp. nov., for these strains. The type strain is UQM 2034.
\end{abstract}

In the course of an examination of the microorganisms in an infusion of litter from the base of a pine tree in Alderley, Brisbane, Australia, we isolated long, filamentous, gliding microorganisms which, in an aging culture, transformed into a mass of coccoid bodies that were somewhat similar to the myxospores of Sporocytophaga myxococcoides.

After this first isolation, we isolated only four additional strains from widely separated areas over a period of 19 months. A detailed examination of these strains has shown that they are very similar to each other but differ markedly from the published descriptions of both S. myxococcoides and Lysobacter species.

\section{MATERIALS AND METHODS}

Bacterial strains. The bacterial strains used in this study are listed in Table 1.

Method of isolation. Samples were collected from the littoral zones of lakes and creeks in sterile collection jars. Pine litter was collected and steeped in sterile distilled water at room temperature (ca. $22^{\circ} \mathrm{C}$ ) for 7 days.

The medium used for all isolations was made from University Lake water, which was filtered through a $0.45-\mu \mathrm{m}$ Sartorius membrane filter to remove all optically visible particles and solidified with $1.5 \%$ agar (Difco Laboratories, Detroit, Mich.). This medium was sterilized at $121^{\circ} \mathrm{C}$ for $15 \mathrm{~min}$ and dispensed in $10-\mathrm{ml}$ amounts in 9-cm plastic petri dishes. The pH was not adjusted.

The isolation medium was inoculated by allowing 1 drop (ca. $0.05 \mathrm{ml}$ ) of undiluted sample to flow in a narrow band across the surface of each agar plate a little off center. The plates were then freed of surface moisture by exposure to $22^{\circ} \mathrm{C}$ for $10 \mathrm{~min}$ in a sterile atmosphere. Such drying minimized the tendency of flagellated organisms to spread across the surface.

Plates were incubated at $22^{\circ} \mathrm{C}$ and examined periodically for up to $24 \mathrm{~h}$ by using the $10 \times$ objective of a phase-contrast microscope to observe microcolony development.

Single filaments of the gliding microorganism were selected with a microloop (15).

Isolated cells were transferred to lake water agar supplemented with $0.01 \%$ peptone (Difco) and $0.01 \%$ yeast extract (Difco) (designated LWPYEA; pH 6.8), which supported more luxuriant growth than unsupplemented lake water agar. Subsequently, cultures were stored on Casitone yeast extract agar (CYEA) containing $0.5 \%$ Casitone (Difco), $0.3 \%$ yeast extract (Difco), 0.1\% magnesium sulfate, and $1.5 \%$ agar (Difco).

Cultures on CYEA were incubated for $48 \mathrm{~h}$ at $22^{\circ} \mathrm{C}$ and then were suspended in Mist Desiccans (7) for freeze-drying by using the methods and equipment described by Skerman (16). The ampoules were filled with oxygen-free nitrogen and were stored at $4^{\circ} \mathrm{C}$.

For liquid nitrogen storage, cells were harvested from CYEA and suspended to a density of ca. $10^{9}$ cells per $\mathrm{ml}$ in filtered lake water containing $10 \%$ glycerol. This suspension was distributed in 0.5 -ml quantities into 0.7-ml ampoules (Snapoules; type NS-33; Wheaton Goldband). These ampoules were sealed and precooled to $-20^{\circ} \mathrm{C}$ for $2 \mathrm{~h}$ before storage in a Union Carbide LD-30 liquid nitrogen container.

Cell morphology, motility, generation time, and colonial development. Cell morphology, motility, generation time, and colonial development were studied by using cultures grown on surface-dried LWPYEA solidified with Noble agar (Difco). A small block of agar (Fig. 1) containing cells was inverted on the surface of the medium and rubbed carefully across it to avoid damage to the mirror-like surface of the medium and to dilute the sample in the process. Noble agar (Difco) was used because it is optically clear.

Each culture was incubated at $22^{\circ} \mathrm{C}$ until active reproduction was observed, usually $16 \mathrm{~h}$. Using a microprobe (15), we drew a line (Fig. 1) across the surface of the agar that was parallel to the band of growth and was separated from it by a distance equal to two field diameters of the $10 \times$ phase-contrast objective. Using a sterile microloop and a Leitz $32 \times$ PHACO phase-contrast objective, we selected single cells from several microcolonies in the early logarithmic phase of growth and relocated them along the line at intervals of ca. $500 \mu \mathrm{m}$ (Fig. 1). Then the plate was incubated for $24 \mathrm{~h}$, the microcolonies were examined, and, if necessary, the cells were separated by a microprobe before they were counted and measured. This technique allowed several replicates to be made on one plate for the determination of generation time.

To study colony development, single cells were im- 
TABLE 1. Strains used

\begin{tabular}{|c|c|c|c|}
\hline $\begin{array}{l}\text { Laboratory } \\
\text { no. }\end{array}$ & Received as: & Source & Habitat \\
\hline UQM 2034 & Original isolate & Alderley $^{a}$ & $\begin{array}{l}\text { Pine lit- } \\
\text { ter }\end{array}$ \\
\hline UQM 2035 & Original isolate & $\mathrm{UQ}^{b}$ & $\begin{array}{l}\text { Fresh } \\
\text { water }\end{array}$ \\
\hline UQM 2036 & Original isolate & Somerset $\mathrm{Dam}^{c}$ & $\begin{array}{l}\text { Fresh } \\
\text { water }\end{array}$ \\
\hline UQM 2037 & Original isolate & Crooked Creek $^{d}$ & $\begin{array}{l}\text { Fresh } \\
\text { water }\end{array}$ \\
\hline UQM 2096 & Original isolate & Hinze Dam ${ }^{e}$ & $\begin{array}{l}\text { Fresh } \\
\text { water }\end{array}$ \\
\hline UQM 1962 & $\begin{array}{l}\text { S. myxococ- } \\
\text { coides NCIB } \\
9920\end{array}$ & & Soil \\
\hline UQM 70 & E. coli & SHL $^{f}$ & \\
\hline UQM 495 & $\begin{array}{c}\text { P. aeruginosa } \\
\text { NCIB } 8295\end{array}$ & & \\
\hline UQM 40 & $\begin{array}{l}\text { B. subtilis } \\
\text { ATCC } 6051\end{array}$ & $\mathrm{ATCC}^{g}$ & \\
\hline UQM 556 & S. aureus & $\operatorname{CSL}^{h}$ & \\
\hline UQM 268 & $\begin{array}{l}\text { "M. lysodeikti- } \\
\text { cus" } "\end{array}$ & $\mathbf{U M}^{j}$ & \\
\hline
\end{tabular}

${ }^{a}$ Alderley, Brisbane, Australia (latitude, $27^{\circ} 30^{\prime}$; longitude $\left.153^{\circ}\right)$.

${ }^{b}$ UQ, University of Queensland, Brisbane, Australia (latitude, $27^{\circ} 30^{\prime}$; longitude, $153^{\circ}$ ).

'Somerset Dam, Queensland, Australia (latitude $27^{\circ} 5^{5}$; longitude, $152^{\circ} 35^{\prime}$ ).

${ }^{d}$ Crooked Creek, Nyngan, New South Wales, Australia (latitude, $31^{\circ} 35^{\prime}$; longitude, $147^{\circ} 12^{\prime}$ ).

${ }^{e}$ Hinze Dam, Queensland, Australia (latitude, $28^{\circ} 5^{\prime}$; longitude, $153^{\circ} 20^{\prime}$ ).

${ }^{f}$ SHL, State Health Laboratory, Brisbane, Australia.

${ }^{\text {a }}$ ATCC, American Type Culture Collection, Rockville, Md

${ }^{\text {h }}$ CSL, Commonweatlh Serum Laboratories, Parkville, Victoria, Australia.

${ }^{i}$ Not on the Approved Lists of Bacterial Names (16).

${ }^{j}$ UM, University of Melbourne, Parkville, Victoria, Australia.

planted in the centers of squares (Fig. 1) marked on the agar surface with a microprobe several millimeters away from the initial line of inoculation. The plate was incubated and examined daily for colony development.

Motility was observed directly with the Leitz $32 \times$ PHACO objective on the surface of the surface-dried agar in the "slime trails" left by the gliding organisms. Flexing of cells was observed in the liquid freed by an incision made (Fig. 1) in the agar with a sterile scalpel toward the end of the band of the inoculum at the time of inoculation.

Myxospore germination. Myxospore germination was observed in colonies growing on LWPYEA. To study myxospore germination, we selected several myxospores with a microloop and positioned them ca. $30 \mu \mathrm{m}$ from each other in a square marked on the agar surface with a microprobe. Observing the square with a Zeiss stereoscopic plate microscope, we positioned a clean sterile no. 1 cover glass centrally over the square. The myxospores were then located with a $10 \times$ phasecontrast objective before examination with a $100 \times$ oil immersion phase-contrast objective.

To do this, a maximum of $10 \mathrm{ml}$ of agar was used in each dish, which permitted focussing of the phasecontrast condenser.
The germination of the myxospores and subsequent growth were recorded with an Olympus PM-6 camera attachment equipped with an EMM-6 exposure meter; Kodak Plus-X Pan film and a green filter were used.

Physiological and biochemical properties. To inoculate media for the physiological and biochemical tests, we used the growth from the margins of spreading colonies.

The basal medium for all physiological tests contained $5 \mathrm{~g}$ of Casitone (Difco), $3 \mathrm{~g}$ of yeast extract (Difco), $1 \mathrm{~g}$ of $\mathrm{MgSO}_{4} \cdot 7 \mathrm{H}_{2} \mathrm{O}$ (Univar), and $1,000 \mathrm{ml}$ of distilled water. This medium was solidified with $1.5 \%$ agar (Difco). The $\mathrm{pH}$ was not adjusted.

For the following tests, we used previously reported methods: hydrolysis of agar (8), cellulose, chitin, starch, and alginate (14); catalase (14), oxidase (6), urease (14), and indole production; nitrate reduction; deposition of iron from ferric ammonium citrate agar; hemolysis of horse erythrocytes; liquefaction of gelatin; hydrolysis of casein (14); utilization of carbohy. drates (14); benzidine test for porphyrins (14); adsorption of Congo red (12); sensitivity to sodium lauryl sulfate (3); deamination of phenylalanine and tryptophan (1); and deoxyribonucleic acid hydrolysis (5).

The ability to lyse bacterial cells was tested on LWPYEA. The plates were block-inoculated (Fig. 1) with host organisms UQM 70, UQM 495, UQM 40, UQM 556, and UQM 268 (Table 1) and were incubated

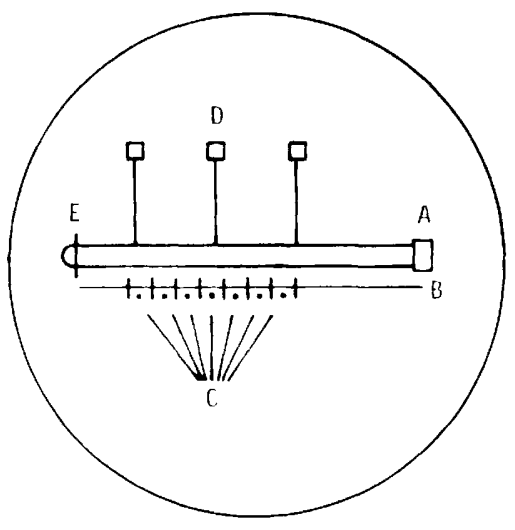

FIG. 1. Diagrammatic illustration of the method of inoculation of plates and subsequent location of cells by micromanipulation. A, A block of agar supporting the inoculum was inverted and drawn across the agar surface from $E$ to $A$. $B, A$ line was drawn with a microprobe parallel to the band of inoculation. $C$, Points of location of single cells over line $B$ for study of cell development and estimation of generation time. $D$, Small squares were drawn with a microprobe around positions where single cells were deposited to study colony development. Each square was joined by a microprobe line to the edge of the band of inoculation for ease of location for subsequent observations. E, An incision was made with a small scalpel at the time of inoculation. Motility and flexing movements of cells could be observed in the water released into the incision. 
for $24 \mathrm{~h}$ at room temperature $\left(22^{\circ} \mathrm{C}\right)$. A small block of agar supporting actively proliferating cells was taken from the edge of a colony of each gliding organism and placed in the center of the growth of the host organism. The plates were incubated for 7 days at $22^{\circ} \mathrm{C}$ and were examined for lysis of the host cells.

The temperature range for growth was determined in Casitone yeast extract liquid medium in a temperature gradient incubator with the range set from 5 to $47^{\circ} \mathrm{C}$. The optimum temperature was determined from the tube in which maximum turbidity occurred, and the minimum and maximum temperatures were determined from tubes in which any visible growth occurred.

For $\mathrm{pH}$ range determinations, melted and cooled, sterile, double-strength CYEA was added to equal volumes of warmed sterile $0.02 \mathrm{M}$ citrate phosphate buffers (for $\mathrm{pH}$ values of 3,4 , and 5 ) and $0.02 \mathrm{M}$ phosphate buffers (for $\mathrm{pH}$ values of 6,7 , and 8) (4); for $\mathrm{pH}$ values of 9,10 , and 11 , the $\mathrm{pH}$ of sterile CYEA (melted and cooled to $55^{\circ} \mathrm{C}$ ) was adjusted by adding calculated amounts of sterile $1 \mathrm{~N} \mathrm{NaOH}$. Growth and maximum degree of growth were determined microscopically.

For salt tolerance determinations, sodium chloride was added to CYEA to give final concentrations of 0.5 , $1.0,1.5,2.0,2.5$, and $3.0 \%$.

A cell suspension in Casitone yeast extract liquid medium incubated for $24 \mathrm{~h}$ in a model G24 environmental incubator-shaker (New Brunswick Scientific Co., Inc., New Brunswick, N.J.) at $22^{\circ} \mathrm{C}$ was used as the inoculum for the $\mathrm{pH}$ tolerance and salt tolerance tests. Each plate was inoculated with 1 drop (ca. 0.05 $\mathrm{ml}$ ) of inoculum, which was allowed to run across the plate; the plate was then air dried. Plates were incubated for 7 days at $22^{\circ} \mathrm{C}$ and observed for inhibition of growth.

For antibiotic susceptibility tests, 1 drop of a cell suspension was spread over the surface of each CYEA plate, which was then air dried. Susceptibility disks (Mast Laboratories, Liverpool, England) were then applied to the inoculated surfaces. The following disks were used: tetracycline, $10 \mu \mathrm{g}$; streptomycin, $10 \mu \mathrm{g}$; neomycin, $10 \mu \mathrm{g}$; kanamycin, $30 \mu \mathrm{g}$; penicillin $\mathrm{G}, 4 \mathrm{U}$; erythromycin, $5 \mu \mathrm{g}$; and chloramphenicol, $25 \mu \mathrm{g}$. Plates were incubated for 4 days at $22^{\circ} \mathrm{C}$ and then observed for inhibition of growth.

The color of any pigment produced was recorded from growth on CYEA after 3 days of incubation at $22^{\circ} \mathrm{C}$.

Guanine-plus-cytosine content of the deoxyribonucleic acid. Deoxyribonucleic acid was extracted by the method of Marmur (10). The guanine-pluscytosine content of the extracted deoxyribonucleic acid was determined by using the melting temperature method of Marmur and Doty (11).

Electron microscopy. Cells were grown in Casitone yeast extract liquid medium. After incubation in the environmental incubator-shaker at $350 \mathrm{rpm}$ and $22^{\circ} \mathrm{C}$ for $72 \mathrm{~h}$, cells were harvested by centrifugation at $7,000 \times g$ for $10 \mathrm{~min}$. The method of Luft (9) was used for fixing, embedding, and staining the specimens.

Sections were cut with a model OMU 2 microtome (Reichert, Vienna, Austria) and examined with a model EM 300 transmission electron microscope (N.
V. Philips Gloeilampenfabrieken, Eindhoven, The Netherlands).

\section{RESULTS}

Colony development. The colony development of this microorganism on the surface of lake water agar was characteristic of most gliding bacteria; i.e., the size increased with age until the surface of the plate was covered. On CYEA (a much richer medium), two strains, UQM 2036 and UQM 2096, produced more elevated colonies, with little evidence of spreading.

Pigment production was not evident on lake water agar, as growth was sparse. Massed cells had a pale yellow color. On CYEA, where heavier growth occurred, a translucent yellowish pigment was produced in the colonies.

The advancing edge of each colony was composed of a monolayer of long, filamentous, gliding cells (Fig. 2A). Immediately behind the advancing edge, multilayer development commenced, and the sizes of the cells began to change, resulting ultimately in the production of masses of spherical myxospores on the agar. Slime trails were clearly visible on plates when the growth was not covered with a cover glass, but were not visible in preparations which were covered.

Formation of myxospores. It was very difficult to follow the formation of myxospores. In situ it was not possible to resolve the process optically because of the density of the cells. Micromanipulation of cells of different sizes to a fresh agar surface resulted in regrowth into long filaments. Evidence obtained by phase-contrast microscopy suggested that the final spherical myxospores resulted from the division of short, plump rods (Fig. 2B and C). This hypothesis was supported by thin sections of cells in the final stages of myxospore formation (Fig. $3 \mathrm{~B})$. The structure of the mature myxospores (Fig. 3C) contrasted strikingly with the structure of the vegetative cells (Fig. 3A) and resembled the structures of myxospores of other genera.

Germination of myxospores. When isolated on an agar surface, single, spherical myxospores germinated without any clear evidence of shedding of a capsule, as described by Leadbetter (E. R. Leadbetter, Bacteriol. Proc., p. 42, 1963) for $S$. myxococcoides. The stages in germination differed with different myxospores from the same and different populations. In some instances, the spherical body elongated into a short, plump rod which underwent division at an early stage, producing two short, plump rods, each of which elongated to produce a long filament (Figs. 4 and 5). In the preparation of the specimen from which growth was recorded in Fig. 5, single spores were positioned on the 

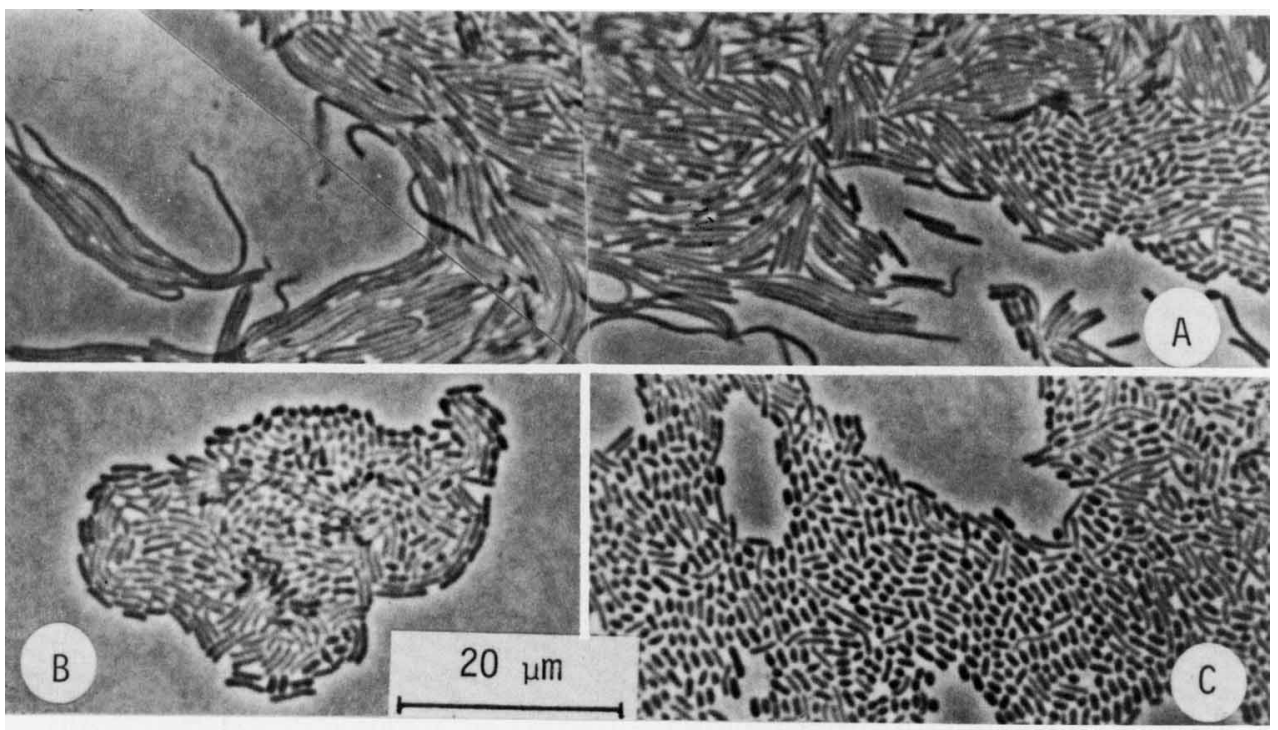

FIG. 2. Transition from the filamentous gliding cells of C. pinensis UQM 2034 to myxospores on LWPYEA. (A) Various stages, from the long filamentous cells found at the margin of a band of growth to stages immediately preceding the formation of spherical myxospores. (B) and (C) Advanced stages, in which some spherical myxospores and some short rods in the final stage of division are visible. (B) Isolated microcolony near the center of a band of growth (see Fig. 1), where competition between numerous small colonies forced an early transition to myxospores. Long filaments are no longer visible.

agar. The two rods in Fig. 5A originated from one myxospore, the germination of which followed the pattern shown in Fig. 4. In other preparations, a single spore elongated to the full extent of the mature filament before division (Fig. 6). The alteration in the position of the filaments (Fig. 6) showed that active movement could occur during the elongation phase.

We attempted to germinate the myxospores of $S$. myxococcoides strain NCIB 9920. Numerous single myxospores were separated from cultures grown on both cellulose and glucose agars, but none germinated. This contrasted markedly with the results described by Leadbetter (Bacteriol. Proc., p. 42, 1963). Populations of spores subjected to increasing degrees of sonication to the point of almost total disintegration showed no alteration in the germination capacity of the surviving spores. The reason for failure to obtain germination is not clear.

Physiological and biochemical data are shown in Tables 2 and 3.

\section{DISCUSSION}

The organism described here differs from $S$. myxococcoides in the following ways: the individual mature cells are approximately four times as long; they produce myxospores which do not show the high refractivity of $S$. myxococcoides; they hydrolyze chitin but not cellulose; and the guanine-plus-cytosine content of the deoxyribo- nucleic acid differs by approximately $9 \%$ from the value reported for $S$. myxococcoides. This organism differs from species of Lysobacter in its abundant production of myxospores and by approximately $20 \%$ in the guanine-plus-cytosine content of its deoxyribonucleic acid (2).

Consequently, we propose a new genus, $\mathrm{Chi}$ tinophaga (Chi. ti. no'pha.ga. M. L. noun chitinum chitin; Gr. v. phagein to devour; M. L. fem. n. Chitinophaga chitin destroyer), the diagnosis of which follows.

Flexible rods with rounded ends; cells measure 0.5 to 0.8 by $40 \mu \mathrm{m}$ in the mature gliding stage and occur singly. A resting stage (a myxospore) 0.8 to $0.9 \mu \mathrm{m}$ in diameter is formed but is not highly refractile. Motile by gliding and flexing. Gram negative.

Chemoorganothrophic; metabolism is oxidative and fermentative. Acid is produced slowly from glucose, lactose, and sucrose. Chitin is hydrolyzed. Cellulose, starch, alginate, and agar are not hydrolyzed. Deoxyribonucleic acid is not hydrolyzed. Phenylalanine and tryptophan deaminase are not produced. Nitrate is not reduced to nitrite. Urease is produced.

Catalase positive, oxidase-negative, benzidine test positive. Horse erythrocytes are hemolyzed. Hydrogen sulfide and indole are not produced. Congo red is not adsorbed. Tween 80, Tween 40, and Tween 20 are hydrolyzed.

Susceptible to the following antibiotics: tet- 


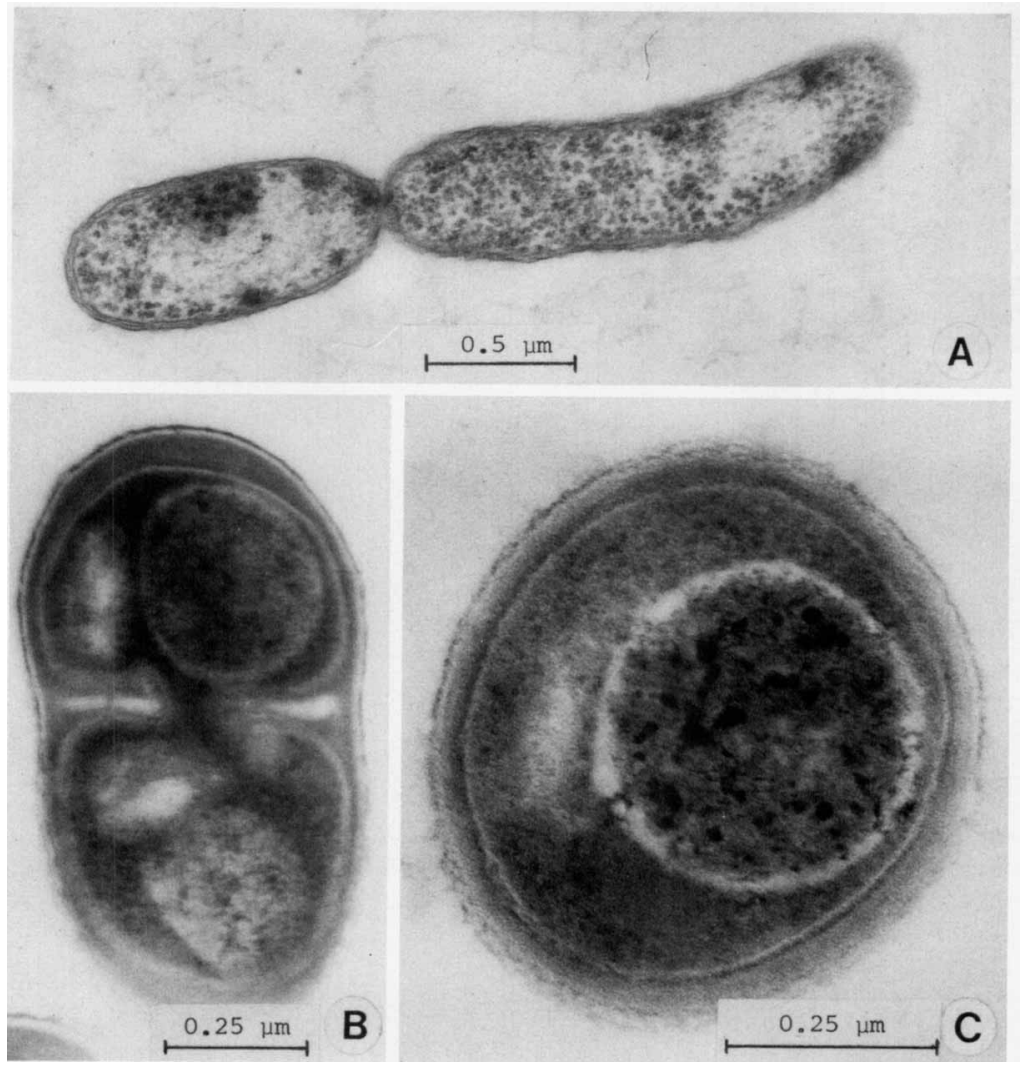

FIG. 3. Thin sections of cells and myxospores of C. pinensis UQM 2036. (A) Tangential section of dividing vegetative cells. (B) Median section of the terminal stage of division, which results in the production of a spherical myxospore. (C) Transverse section of a myxospore.

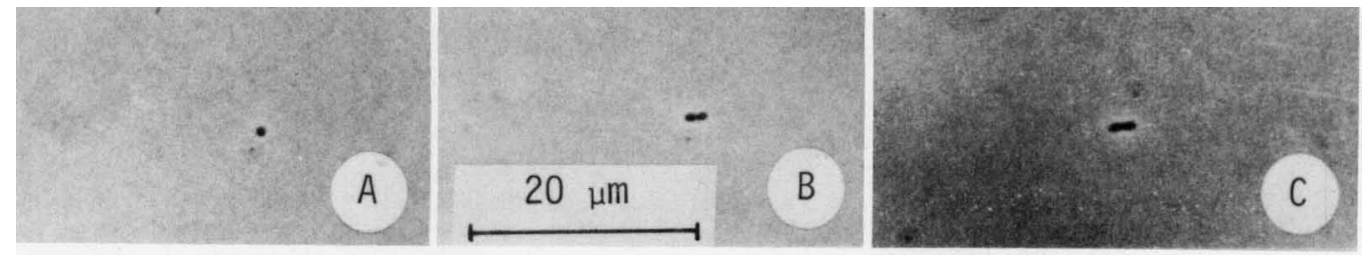

FIG. 4. Early stages in one form of germination of C. pinensis UQM 2036 myxospores. Times after micromanipulation of the myxospores: zero time $(A), 3 h(B)$, and $5 h(C)$.

racycline, streptomycin, and chloramphenicol. Not susceptible to neomycin, kanamycin, penicillin G, or erythromycin. Resistant to 0.01 but not $0.1 \%$ sodium lauryl sulfate.

Lyses Staphylococcus aureus cells but not cells of Escherichia coli, Pseudomonas aeruginosa, Bacillus subtilis, or "Micrococcus lysodeikticus" (not on the Approved Lists of Bacterial Names [17]).

Cell masses are yellow. Temperature for growth, 12 to $37^{\circ} \mathrm{C}$. $\mathrm{pH}$ range, 4 to 10 .

The guanine-plus-cytosine contents of the de- oxyribonucleic acids of five strains ranged from 42.88 to $45.61 \mathrm{~mol} \%$ (thermal denaturation method). The five strains which have been examined differ only in very minor cultural characteristics and consequently are assigned to one species, for which the name Chitinophaga pinensis (M. L. n. Pinus genus of pine trees; M.L. adj. pinensis pertaining to pines) is proposed. The type strain is UQM 2034.

As there is only one species, the species description is the same as that given above for the genus. 


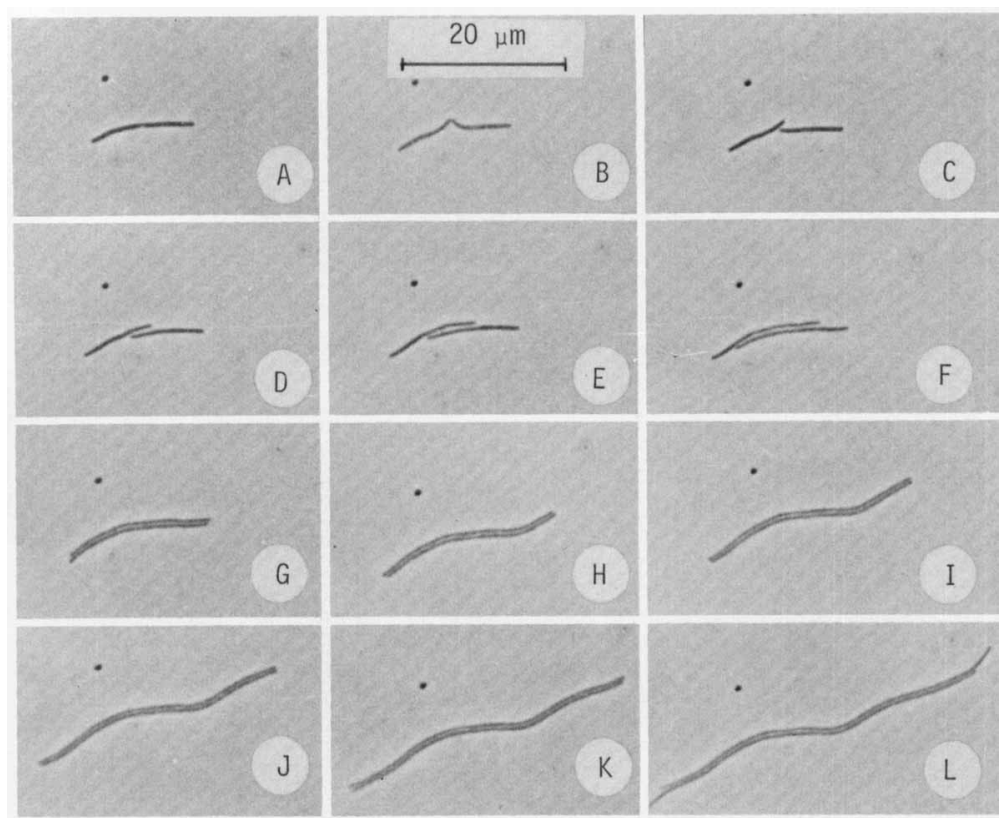

FIG. 5. Stages in the germination and growth of C. pinensis UQM 2036 from a myxospore on LWPYEA at $22^{\circ} \mathrm{C}$. An ungerminated myxospore is present in each frame. Times after micromanipulation of myxospores: $11 h(A), 11.33 h(B), 11.41 h(C), 11.75 h(D), 12.25 h(E), 12.75 h(F), 13.25 h(G), 13.75 h(H), 14.25 h(I), 14.75$ $h(J), 15.25 h(K)$, and $15.75 h(L)$.

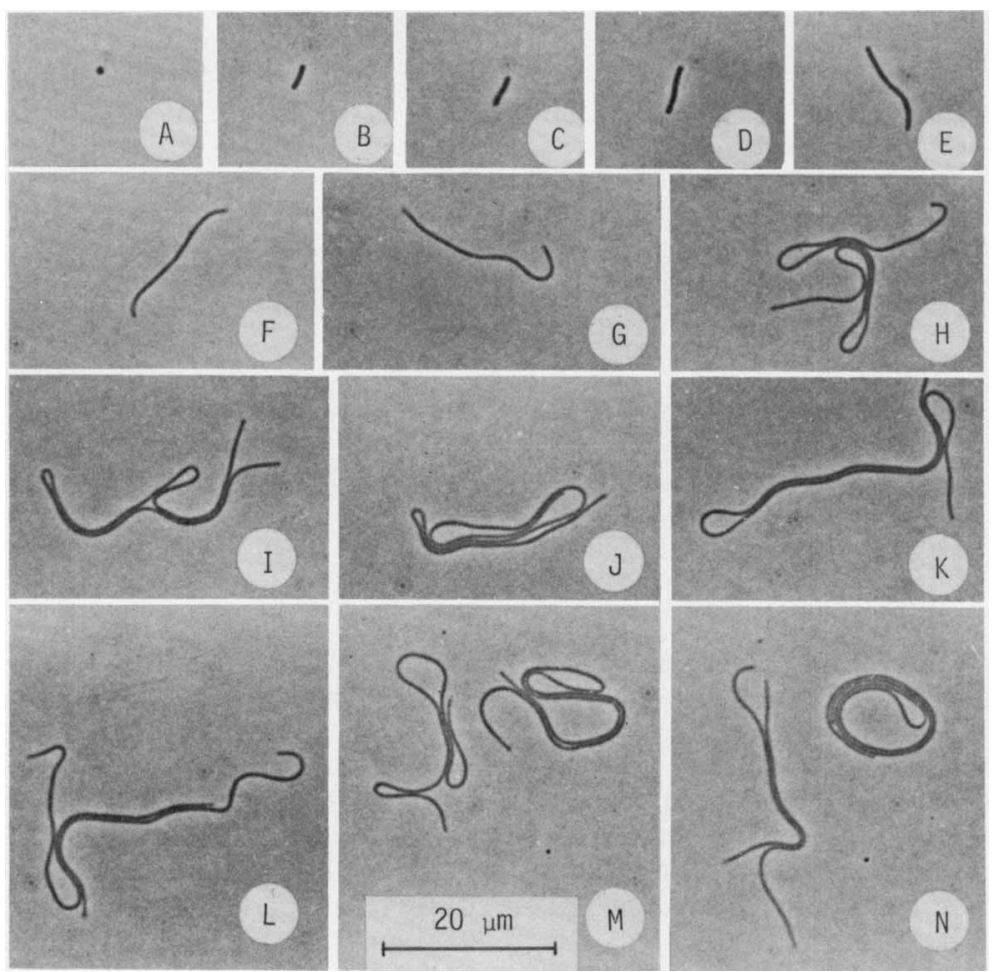

FIG. 6. Stages in the germination and growth of C. pinensis UQM 2034 from a myxospore on LWPYEA at $22^{\circ} \mathrm{C}$. Times after micromanipulation of the myxospore: $1 h(A), 6 h(B), 8 h(C), 9 h(D), 11.5 h(E), 13 h(F), 13.5$ $h(G), 15 h(H), 15.15 h(I), 15.2 h(J), 15.5 h(K), 15.58 h(L), 15.75 h(M)$, and $16 h(N)$. 


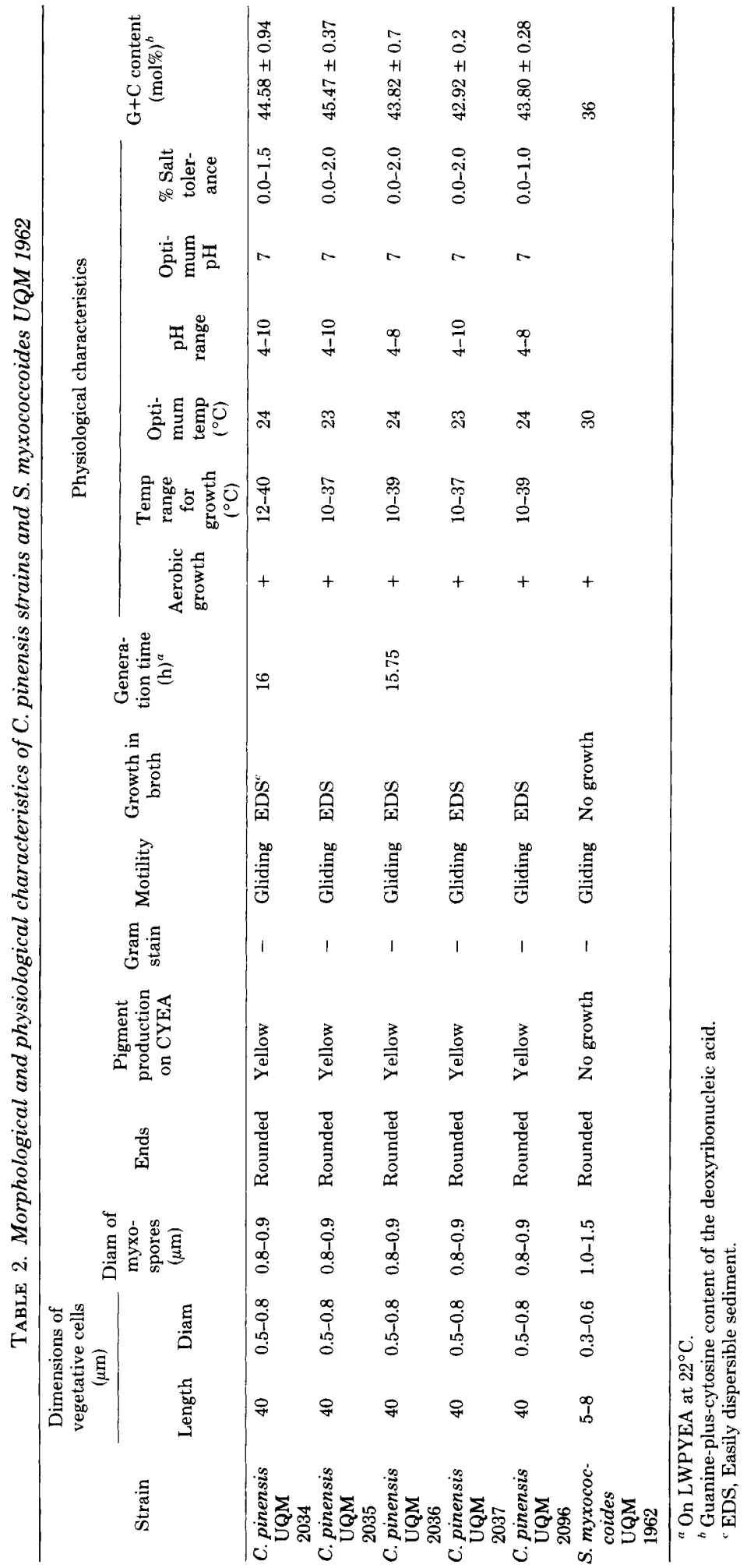


TABLE 3. Test results for C. pinensis strains and S. myxococcoides UQM 1962

\begin{tabular}{|c|c|c|c|c|c|c|}
\hline \multirow[b]{2}{*}{ Test } & \multicolumn{6}{|c|}{ Results with: } \\
\hline & $\begin{array}{l}\text { C. pinensis } \\
\text { UQM } 2034\end{array}$ & $\begin{array}{l}\text { C. pinensis } \\
\text { UQM } 2035\end{array}$ & $\begin{array}{l}\text { C. pinensis } \\
\text { UQM } 2036\end{array}$ & $\begin{array}{l}\text { C. pinensis } \\
\text { UQM } 2037\end{array}$ & $\begin{array}{l}\text { C. pinensis } \\
\text { UQM } 2096\end{array}$ & $\begin{array}{c}\text { S. myxococ- } \\
\text { coides UQM } \\
1962 \\
\end{array}$ \\
\hline \multicolumn{7}{|l|}{ Biochemical } \\
\hline Chitin hydrolysis & + & + & + & + & + & - \\
\hline Cellulose hydrolysis & - & - & - & - & - & + \\
\hline Starch hydrolysis & - & - & - & - & - & - \\
\hline Alginate hydrolysis & - & - & - & - & - & \\
\hline Agar liquefaction & - & - & - & - & - & Agar etching \\
\hline Casein hydrolysis & + & + & + & + & + & - \\
\hline Gelatin liquefaction & + & + & + & + & + & \\
\hline $\begin{array}{l}\text { Phenylalanine deami- } \\
\text { nase }\end{array}$ & - & - & - & - & - & - \\
\hline $\begin{array}{l}\text { Tryptophane deami- } \\
\text { nase }\end{array}$ & - & - & - & - & - & - \\
\hline Nitrate reduction & - & - & - & - & - & \\
\hline Urease & + & + & + & + & + & \\
\hline \multicolumn{7}{|l|}{$\begin{array}{l}\text { Oxidative and fermenta- } \\
\text { tive production of } \\
\text { acid from: }{ }^{a}\end{array}$} \\
\hline Glucose & Slow oxidative & Slow oxidative & Fermentative & Fermentative & Slow oxidative & \\
\hline Lactose & Slow oxidative & Slow oxidative & Fermentative & Fermentative & Slow oxidative & \\
\hline Sucrose & Slow oxidative & Slow oxidative & Fermentative & Fermentative & Slow oxidative & \\
\hline \multicolumn{7}{|l|}{$\begin{array}{l}\text { Miscellaneous biochem- } \\
\text { istry }\end{array}$} \\
\hline Catalase & + & + & + & + & + & + \\
\hline Oxidase & - & - & - & - & - & - \\
\hline $\mathrm{H}_{2} \mathrm{~S}$ production & - & - & - & - & - & \\
\hline Indole production & - & - & - & - & - & \\
\hline Congo red adsorption & - & - & - & - & - & \\
\hline $\begin{array}{l}\text { Deoxyribonucleic acid } \\
\text { hydrolysis }\end{array}$ & - & - & - & - & - & \\
\hline $\begin{array}{l}\text { Hemolysis of horse } \\
\text { erythrocytes }\end{array}$ & + & + & + & + & + & \\
\hline $\begin{array}{l}\text { Benzidine test for iron } \\
\text { porphyrins }\end{array}$ & + & + & + & + & + & \\
\hline Lipase (Tween 80) & + & + & + & + & + & \\
\hline Lipase (Tween 40) & + & + & + & + & + & \\
\hline Lipase (Tween 20) & + & + & + & + & + & \\
\hline \multicolumn{7}{|l|}{ Antibiotic susceptibility } \\
\hline Tetracycline $(10 \mu \mathrm{g})$ & $\mathrm{S}^{b}$ & $\mathbf{S}$ & $\mathbf{S}$ & $\mathbf{S}$ & $\mathbf{S}$ & \\
\hline Streptomycin $(10 \mu \mathrm{g})$ & $\mathrm{S}$ & $\mathrm{S}$ & $\mathbf{S}$ & $\mathbf{S}$ & $\mathbf{S}$ & \\
\hline Neomycin $(10 \mu \mathrm{g})$ & $\mathrm{R}$ & $\mathbf{R}$ & $\mathbf{R}$ & $\mathbf{R}$ & $\mathbf{R}$ & \\
\hline Kanamycin $(30 \mu \mathrm{g})$ & $\mathbf{R}$ & $\mathbf{R}$ & $\mathbf{R}$ & $\mathbf{R}$ & $\mathbf{R}$ & \\
\hline Penicillin G (4 U) & $\mathbf{R}$ & $\mathbf{R}$ & $\mathbf{R}$ & $\mathbf{R}$ & $\mathbf{R}$ & \\
\hline Erythromycin $(5 \mu \mathrm{g})$ & $\mathbf{R}$ & $\mathbf{R}$ & $\mathbf{R}$ & $\mathbf{R}$ & $\mathbf{R}$ & \\
\hline $\begin{array}{l}\text { Chloramphenicol (25 } \\
\mu \mathrm{g})\end{array}$ & $\mathbf{S}$ & $\mathbf{S}$ & $\mathbf{S}$ & $\mathbf{S}$ & $\mathbf{S}$ & \\
\hline $\begin{array}{l}\text { Susceptibility to } 0.01 \% \\
\text { sodium lauryl sul- } \\
\text { fate }\end{array}$ & $\mathbf{R}$ & $\mathbf{R}$ & $\mathbf{R}$ & $\mathbf{R}$ & $\mathbf{R}$ & \\
\hline $\begin{array}{l}\text { Susceptibility to } 0.1 \% \\
\text { sodium lauryl sul- } \\
\text { fate }\end{array}$ & $\mathbf{S}$ & $\mathrm{S}$ & $\mathbf{S}$ & $\mathbf{S}$ & $\mathbf{S}$ & \\
\hline \multicolumn{7}{|l|}{ Ability to lyse: } \\
\hline E. coli & - & - & - & - & - & \\
\hline P. aeruginosa & - & - & - & - & - & \\
\hline B. subtilis & - & - & - & - & - & \\
\hline S. aureus & + & + & + & + & + & \\
\hline "M. lysodeikticus" & - & - & - & - & - & \\
\hline
\end{tabular}

${ }^{a}$ Observation period, 3 weeks.

${ }^{b} \mathrm{~S}$, Susceptible; $R$, resistant.

${ }^{\mathrm{e}}$ Not on the Approved Lists of Bacterial Names (16).

\section{REPRINT REQUESTS}

No reprints available.

\section{LITERATURE CITED}

1. Bøvre, K., and S. D. Henriksen. 1967. A revised description of Moraxella polymorpha Flamm 1957, with a proposal of a new name, Moraxella phenylpyrouvica, for this species. Int. J. Syst. Bacteriol. 17:343-360.

2. Christensen, P., and F. D. Cook. 1978. Lysobacter, a new genus of non-fruiting, gliding bacteria with a high base ratio. Int. J. Syst. Bacteriol. 28:367-393.

3. Christensen, P. J., and F. D. Cook. 1972. The isolation 
and enumeration of cytophagas. Can. J. Microbiol. 18: 1933-1940.

4. Cruickshank, R., et al. 1975. Medical microbiology, 12th ed., vol. 2. The practice of medical microbiology. Churchill Livingstone, Edinburgh.

5. Jeffiries, C. D., D. F. Holtman, and D. G. Guse. 1957. Rapid method of determining the activity of microorganisms on nucleic acids. J. Bacteriol. 73:590-591.

6. Kovacs, N. 1956. Identification of Pseudomonas pyocyanea by the oxidase reaction. Nature (London) 178: 703.

7. Lapage, S. P., J. E. Shelton, T. G. Mitchell, and A. R. Mackenzie. 1970. Culture collections and preservation of bacteria, p. 135-227. In J. R. Norris and D. W. Ribbons (ed.), Methods in microbiology, vol. 3A. Academic Press, Inc., London.

8. Lewin, R. A., and D. M. Lounsbery. 1969. Isolation, cultivation and characterization of flexibacteria. J. Gen. Microbiol. 58:145-170.

9. Luft, J. H. 1971. Ruthenium red and violet. I. Chemistry, purification, methods of use for electron microscopy and mechanism of action. Anat. Rec. 171:347-368.

10. Marmur, J. 1961. A procedure for the isolation of deoxyribonucleic acid from microorganisms. J. Mol. Biol. 3: 208-218.
11. Marmur, J., and P. Doty. 1962. Determination of base composition of deoxyribonucleic acid from its thermal denaturation temperature. J. Mol. Biol. 5:109-118.

12. McCurdy, H. D. 1969. Studies on the taxonomy of the Myxobacterales. I. Record of Canadian isolates and survey of methods. Can. J. Microbiol. 15:1453-1461.

13. Sierra, G. 1957. A simple method for the detection of lipolytic activity of microorganisms and some observations on the influence of the contact between cells and fatty substrates. Antonie van Leeuwenhoek J. Microbiol. Serol. 23:15-22.

14. Skerman, V. B. D. 1967. A Guide to the identification of the genera of bacteria, 2nd ed. The Williams \& Wilkins Co., Baltimore.

15. Skerman, V. B. D. 1968. A new type of micromanipulator and microforge. J. Gen. Microbiol. 54:287-297.

16. Skerman, V. B. D. 1973. The organisation of a small general collection, p. 20-40. In A. F. Pestano de Castro, E. J. DaSilva, V. B. D. Skerman, and W. W. Leveritt (ed.), Proceedings of the Second International Conference on Culture Collections. Courier Mail Printing Office, Bowen Hills, Australia.

17. Skerman, V. B. D., V. McGowan, and P. H. A. Sneath (ed.). 1980. Approved lists of bacterial names. Int. J. Syst. Bacteriol. 30:225-420. 